\title{
ALGORITMA OPTIMASI UNTUK PENYELESAIAN TRAVELLING SALESMAN PROBLEM
}

(Optimization Algorithm for Solving Travelling Salesman Problem)

\author{
Dian Tri Wiyanti \\ Program Studi Teknik Informatika, Jurusan Teknologi Informasi \\ Fakultas Teknologi Informasi dan Komunikasi, Universitas Semarang \\ Email: dian@usm.ac.id
}

\begin{abstract}
Travelling Salesman Problem (TSP) is still a hot topic for discussion. TSP includes part of optimization problems in a real world. In the TSP, there are cities that must be passed by a salesman, then back to the city where he first set out. In that way, a salesman should be choose the shortest route. There are many algorithms for solving TSP problem. And among the many algorithms, in this study will be discussed on how the algorithm implementation of Greedy, Artificial Bee Colony $(A B C)$, Cheapest Insertion Heuristics (CIH), and Genetics algorithm to resolve the case of TSP. Analysis that is performed are a comparison of methods, implementation of the TSP case, as well as the advantages and disadvantages of each algorithm
\end{abstract}

Keywords: TSP, Algorithm Optimization, Comparison

\section{PENDAHULUAN}

Travelling Salesman Problem (TSP) merupakan masalah klasik mencari rute terpendek yang bisa dilalui salesman ketika ingin mengunjungi beberapa kota tanpa harus mendatangi kota yang sama lebih dari satu kali [4]. Penyelesaian eksak untuk masalah TSP ini mengharuskan perhitungan terhadap semua kemungkinan rute yang dapat diperoleh, kemudian memilih salah satu rute yang terpendek.

Tinjauan Pustaka. Terdapat banyak algoritma untuk melakukan pencarian rute terpendek. Pemilihan algoritma yang paling optimum selalu menjadi permasalahan dalam pencarian rute terpendek, dimana masingmasing algoritma memiliki kelebihan dan kekurangannya masing-masing. Dalam lingkup pencarian rute terpendek ini tidak dapat dikatakan secara langsung algoritma mana yang paling optimum untuk keseluruhan kasus, karena belum tentu suatu algoritma yang memiliki optimasi yang tinggi untuk suatu kasus memiliki optimasi yang tinggi pula untuk kasus yang lain. Penelitian yang dilakukan oleh [5] memberikan kesimpulan yaitu secara umum algoritma genetika bekerja lebih baik daripada kedua algoritma yang lain, yaitu algoritma Hopfield dan Exhaustive ditinjau dari jarak yang dihasilkan serta waktu yang dibutuhkan untuk melakukan perhitungan pada algoritma. Sedangkan penelitian yang dilakukan [2] memilih menggunakan algoritma $A B C$ karena sederhana dan fleksibel, memiliki kemampuan untuk keluar dari local minimum dan dapat secara efisiensi digunakan untuk multimodal dan multivariable optimasi fungsi. Kemudian penelitian yang dilakukan oleh [1], menyebutkan bahwa algoritma greedy lebih bagus apabila digunakan pada kurang dari 10 tempat tujuan. Karena hasil dari algoritma greedy dan dibanding dengan algoritma lain, algoritma greedy memiliki hasil optimasi yang lebih bagus dan dengan waktu komputasi yang lebih cepat. Selain itu, penelitian oleh [4] menyebutkan waktu proses dari algoritma $\mathrm{ClH}$ jauh lebih cepat, namun untuk memproses kota dalam jumlah besar $\mathrm{ClH}$ masih membutuhkan waktu yang cukup besar pula. 
Kontribusi. Setiap algoritma memiliki kelebihan dan kekurangan masing-masing. Pembahasan dalam paper ini dilakukan mulai dari perbandingan metode, implementasinya terhadap kasus TSP, serta kelebihan dan kekurangan masing-masing algoritma untuk studi kasus pada TSP. Dengan demikian diharapkan akan menambah informasi pada user mengenai algoritma yang paling sesuai digunakan dengan solusi yang paling diinginkan untuk kasus TSP.

\section{PEMBAHASAN}

Beberapa hal yang menjadi perhatian dalam pembahasan ini mencakup 3 hal, yaitu :

a. Konsep TSP

b. Konsep dan implementasi beberapa algoritma terhadap TSP

c. Kelebihan dan kekurangan masingmasing algoritma

\subsection{Konsep TSP}

Apa yang dilakukan dalam TSP adalah membentuk sebuah tour. Operator yang bisa digunakan untuk masalah TSP adalah pencarian urutan semua lokasi untuk memilih lokasi yang belum pernah terpilih satu demi satu sehingga dihasilkan satu rute kunjungan yang lengkap dari lokasi awal kemudian mengunjungi semua lokasi yang lain tepat satu kali dan akhirnya kembali ke lokasi awal. Sehingga dengan definisi tersebut dapat dikatakan bahwa konsep permasalahan TSP memiliki aturan sebagai berikut:

1. Harus mengunjungi setiap kota tepat satu kali, tidak boleh kurang ataupun lebih.

2. Semua kota harus dikunjungi dalam satu kali perjalanan (tour).

3. Dimulai dan diakhiri pada kota yang sama.

Sebagai ilustrasi dengan Gambar 1, diasumsikan bahwa simpul awal dan simpul akhir adalah 1. Suatu graf TSP dengan 4 simpul tersebut dikonversi menjadi sebuah pohon pencarian yang menghasilkan (4-1)! = 6 kemungkinan urutan kunjungan. Sedangkan untuk 50 kota, terdapat sebanyak (50-1)! = $6,08 \times 10^{62}$ kemungkinan urutan kunjungan.

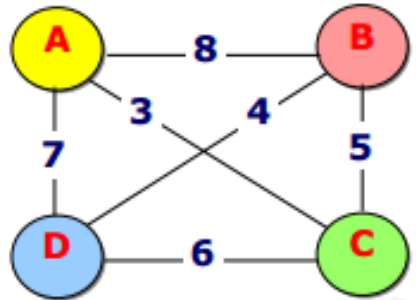

Gambar 1. Contoh Graf Rute Perjalanan

Berdasarkan [6], TSP dikatakan ada 2 jenis, yaitu:

1. TSP asimetris

Pada TSP jenis ini, biaya dari kota $1 \mathrm{ke}$ kota 2 tidak sama dengan biaya dari kota 2 ke kota 1. Dengan $\mathrm{n}$ kota, besarnya ruang pencarian adalah $\frac{n !}{n}=(n-1)$ ! jalur yang mungkin.

2. TSP simetris

Sedangkan pada TSP jenis simetris, biaya dari kota 1 ke kota 2 adalah sama dengan biaya dari kota 2 ke kota 1 . Apabila dengan $n$ kota, jumlah jalur yang mungkin adalah $\frac{n !}{2 n}=\frac{(n-1) !}{2}$ jalur yang mungkin.

\subsection{Konsep dan Implementasi Beberapa Algoritma Terhadap TSP \\ 2.2.1.Algoritma Greedy}

Algoritma greedy merupakan sebuah algoritma yang dapat menentukan sebuah jalur terpendek antara node-node yang akan digunakan dengan mengambil secara terus menerus dan menambahkannya ke dalam jalur yang akna dilewati. Mengacu pada konsep greedy yang menganggap bahwa pada setiap langkah akan dipilih tempat atau kota yang belum pernah dikunjungi, dimana tempat atau kota tersebut memiliki jarak terdekat dari tempat atau kota sebelumnya. Algoritma ini tidak mempertimbangkan nilai heuristic, yang dalam hal ini bisa berupa jarak langsung antar dua tempat.

Sehingga dengan kata lain, dapat dikatakan bahwa langkah dari algoritma greedy ini adalah mengambil pilihan yang terbaik yang dapat diperoleh pada saat itu tanpa memperhatikan konsekuensi ke depan, atau dengan prinsip "take what you can get 
now", berharap bahwa dengan memilih optimum lokal pada setiap langkah akan berakhir dengan optimum global. Dengan prinsip seperti ini dapat dikatakan bahwa algoritma greedy lebih berguna untuk menghasilkan solusi hampiran (approximation). Hal ini dikarenakan algoritma greedy tidak selalu berhasil memberikan solusi yang optimal. Hal ini telah dibuktikan dalam penelitian oleh [1] yang mengaplikasikan algoritma ini terhadap layanan taksi wisata, dimana hasil implementasi algoritma greedy ini dikhususkan pada kasus TSP yang jarak antar node-nodenya pendek.

\subsubsection{Algoritma Artificial Bee Colony}

Pada algoritma $A B C$, pendekatan yang dilakukan adalah population-based metaheuristic, dimana pendekatan ini terinspirasi oleh perilaku cerdas kawanan lebah madu dalam mencari makanan. Ada 3 tahapan utama pada basic algoritma $A B C$, yaitu :

1. Menghasilkan inisial solusi dari sumber makanan secara acak.

Untuk memperbarui solusi yang mungkin, setiap employed bee memilih calon posisi sumber makanan baru, yang mana posisi tersebut berbeda dengan sebelumnya.

2. Setiap onlooker bee memilih salah satu sumber makanan yang diperoleh dari employed bee.

Setelah memilih sumber makanan, onlooker bee pergi ke sumber makanan yang dipilih dan memilih sumber calon makanan baru.

3. Terdapat limit yang telah ditetapkan.

Pada tahapan terakhir, limit adalah batasan yang telah ditetapkan dalam siklus algoritma $A B C$ dan mengendalikan banyaknya solusi tertentu yang tidak diperbarui. Setiap sumber makanan yang tidak meningkat melewati limit akan ditinggalkan dan diganti dengan posisi baru dan employed bee menjadi scout bee.
Dalam penelitian oleh [2], hasil yang didapatkan mencapai nilai optimal, dalam hal ini jarak terpendek. Namun sama seperti penelitian [1], permasalahan pada algoritma $A B C$ yang diterapkan masih terpaku pada jumlah kota yang terbatas. Karena dalam penelitian [2] ini terdapat kesimpulan bahwa jika size problem semakin besar, dalam hal ini jumlah kota yang diproses, maka tingkat kesalahan juga semakin meningkat.

\subsubsection{Algoritma Cheapest Insertion Heuristics}

Kemudian dalam [4], algoritma $\mathrm{ClH}$ dikombinasikan dengan basis data. Dimana basis data digunakan sebagai penyimpanan data proses sehingga pengambilan informasi jarak minimal dari beberapa alternatif yang ada dapat dilakukan dengan mudah yaitu dengan menggunakan query. Konsep $\mathrm{ClH}$ sendiri memiliki algoritma sebagai berikut :

1. Penelusuran

Dimulai dari sebuah kota pertama yang dihubungkan dengan sebuah kota terakhir.

2. Dibuat hubungan subtour

Sebuah hubungan subtour dibuat antara 2 kota tersebut. Yang dimaksud subtour adalah perjalanan dari kota pertama dan berakhir di kota pertama, misal $(1,3) \rightarrow$ $(3,2) \rightarrow(2,1)$ seperti tergambar dalam Gambar 2.

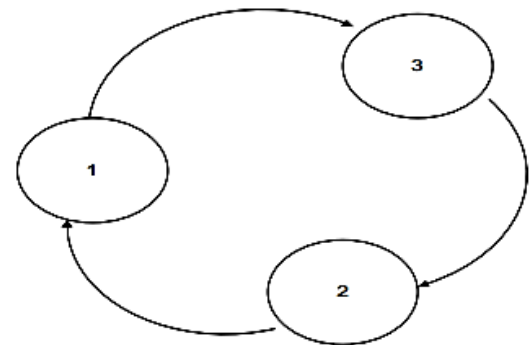

Gambar 2. Subtour

3. Mengganti arah hubungan

Salah satu arah hubungan (arc) dari dua kota diganti dengan kombinasi dua arc, yaitu arc (i,j) dengan arc (i,k) dan arc $(k, j)$, dengan $k$ diambil dari kota yang belum masuk subtour, dan dengan tambahan jarak terkecil. 
Yang mana jarak diperoleh dari:

$$
c_{i k}+c_{k j}-c_{i j}
$$

dimana :

$\mathrm{C}_{\mathrm{ik}}$ adalah jarak dari kota i ke kota $\mathrm{k}$

$\mathrm{C}_{\mathrm{kj}}$ adalah jarak dari kota $\mathrm{k}$ ke kota j

$\mathrm{c}_{\mathrm{ij}}$ adalah jarak dari kota i ke kota j

4. Ulangi langkah 3 sampai seluruh kota masuk dalam subtour.

\subsubsection{Algoritma Genetika}

Sedangkan dalam [5], algoritma genetika berhasil mengoptimalkan hasilnya. Terbukti untuk kasus TSP dengan jumlah kota yang banyak, algoritma genetika dapat menghasilkan rute paling optimum. Namun yang perlu diingat adalah pemilihan parameter input harus dilakukan dengan tepat. Konsep algoritma genetika sendiri adalah algoritma pencarian heuristik yang didasarkan pada mekanisme evolusi biologis. Keberagaman pada evolusi biologis adalah variasi dari kromosom dalam individu organisme. Variasi kromosom ini akan mempengaruhi laju reproduksi dan tingkat kemampuan organisme untuk tetap hidup. Pada dasarnya ada 4 kondisi yang mempengaruhi proses evaluasi, yaitu :

1. Kemampuan organisme untuk melakukan reproduksi.

2. Keberadaan populasi organisme yang bisa melakukan reproduksi.

3. Keberagaman organisme dalam suatu populasi.

4. Perbedaan kekuatan dan kemampuan organisme untuk bertahan hidup.

Adapun langkah-langkah dari algoritma genetika adalah sebagai berikut :

1. Langkah pertama adalah melakukan penentuan nilai awal (inisialisasi). Bagian ini merupakan pemberian input yang dilakukan oleh pengguna.

2. Proses berikutnya adalah proses pembentukan populasi awal. Proses ini berfungsi untuk membentuk populasi generasi pertama.

3. Selanjutnya adalah proses seleksi, dimana setelah terbentuk populasi awal, maka hasil populasi awal itu akan diseleksi.

4. Setelah melakukan proses seleksi, maka hasil dari proses tersebut akan digunakan dalam proses crossover.

5. Sebelum melakukan proses crossover dilakukan pengundian dengan bilangan random untuk setiap kromosom, apakah kromosom tersebut terjadi crossover atau tidak.

6. Jika dari proses pengundian menunjukkan bahwa terjadi crossover maka akan dibuat bilangan random lain untuk menentukan dimana crossover akan terjadi.

7. Setelah proses crossover dijalankan selalu dilakukan pengecekan apakah kromosom yang terkena crossover tersebut merupakan kromosom yang valid, dalam arti kromosom hasil crossover tersebut membentuk suatu rute.

8. Jika terjadi pengulangan individu dalam kromosom, maka dilakukan proses normalisasi untuk membuat kromosom tersebut menjadi valid.

9. Pada saat penyalinan kromosom dilakukan, kromosom tersebut dapat mengalami mutasi, yaitu perubahan isi kromosom, dimana isi dari kromosom tersebut digantikan dengan suatu nilai yang dipilih secara acak dari titik-titik yang ada.

10. Setelah proses mutasi, maka akan dilakukan lagi proses seleksi dan dilakukan pengecekan apakah proses keseluruhan telah selesai atau belum.

\subsection{Kelebihan dan kekurangan masing- masing algoritma}

Perbandingan untuk menyelesaikan kasus TSP dengan menggunakan algoritma greedy, Artificial Bee Colony (ABC), Cheapest 
Insertion Heuristics $(\mathrm{ClH})$, dan algoritma genetika ada pada Tabel 1 berikut.

Tabel 1. Perbandingan Algoritma

\begin{tabular}{|c|c|c|c|c|}
\hline ALGORITMA & Greedy & $A B C$ & $\mathrm{ClH}$ & Genetika \\
\hline KELEBIHAN & $\begin{array}{l}\text { Waktu komputasi } \\
\text { yang dibutuhkan } \\
\text { dalam } \\
\text { menyelesaikan } \\
\text { kasus TSP lebih } \\
\text { cepat. } \\
\text { Lebih sesuai } \\
\text { untuk kasus yang } \\
\text { membutuhkan } \\
\text { solusi hampiran. }\end{array}$ & $\begin{array}{l}\text { Mencapai nilai } \\
\text { optimal apabila } \\
\text { data pada kasus } \\
\text { TSP merupakan } \\
\text { data dengan size } \\
\text { yang tidak terlalu } \\
\text { besar. }\end{array}$ & $\begin{array}{l}\text { Berbeda dengan } \\
\text { algoritma ABC, } \\
\text { algoritma ini masih } \\
\text { stabil digunakan } \\
\text { untuk kasus TSP } \\
\text { dengan jumlah kota } \\
\text { yang besar. }\end{array}$ & $\begin{array}{l}\text { Waktu komputasi yang } \\
\text { dibutuhkan cenderung } \\
\text { stabil. } \\
\text { Mampu memberikan } \\
\text { jarak terpendek meski } \\
\text { dengan jumlah kota } \\
\text { yang besar, bila } \\
\text { dibandingkan dengan } \\
\text { algoritma yang lain. }\end{array}$ \\
\hline KEKURANGAN & $\begin{array}{lr}\text { Hasil } & \text { yang } \\
\text { didapatkan } & \text { tidak } \\
\text { selalu optimal. Hal } & \text { ini } \\
\text { ini } & \text { karena } \\
\text { algoritma } & \text { greedy } \\
\text { masih } & \text { terjebak } \\
\text { dalam optimum } & \text { lokal. }\end{array}$ & $\begin{array}{lr}\text { Kesalahan } & \text { atau } \\
\text { akurasinya } & \\
\text { semakin besar } & \text { seiring dengan } \\
\text { data size } & \text { yang } \\
\text { besar } & \text { pula. } \\
\text { Sehingga } & \\
\text { algoritma } & \text { ini } \\
\text { kurang cocok } \\
\text { untuk kasus } & \text { TSP } \\
\text { dengan jumlah } \\
\text { kota yang besar } \\
\text { dan jarak yang } \\
\text { terlalu lebar. }\end{array}$ & \begin{tabular}{lr}
\multicolumn{2}{c}{ Dengan kelebihan } \\
yang ada pada \\
algoritma ini, \\
banyaknya jumlah \\
kota sangat \\
berpengaruh pada \\
waktu komputasi.
\end{tabular} & 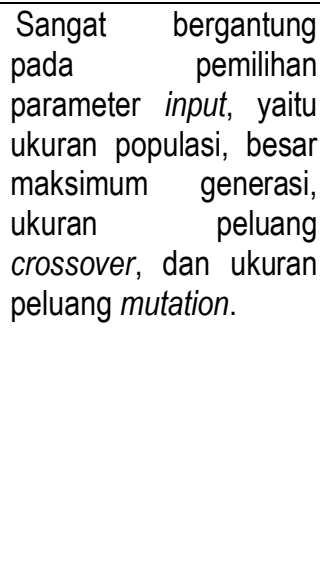 \\
\hline
\end{tabular}

\section{KESIMPULAN}

Berdasarkan asumsi yang ditinjau dari referensi-referensi yang ada, dapat disimpulkan bahwa tidak ada satupun algoritma yang berlaku umum dan bisa digunakan untuk menyelesaikan semua jenis masalah. Dengan apa yang disajikan oleh Tabel I, diharapkan peneliti dan praktisi dapat memilih algoritma optimasi yang paling tepat dan sesuai untuk digunakan, dalam hal ini pada kasus TSP.

\section{DAFTAR PUSTAKA}

[1] A.C. Purnomo, M. Yuliana, dan I. Prasetyaningrum, Implementasi Algoritma Greedy Pada Layanan Taksi Wisata Berbasis Web. [Online]. Available: www.eepis-its.edu/uploadta/downloadmk. [Accessed August 23, 2013].

[2] F. Amri, E.B. Nababan, M.F. Syahputra, Artificial Bee Colony Algorithm untuk Menyelesaikan Travelling Salesman Problem, Jurnal Dunia Teknologi Informasi Vol. 1, No. 1, hal. 8-13, 2012.

[3] J.J. Siang. Riset Operasi Dalam Pendekatan Algoritmis. Yogyakarta: Penerbit Andi, 2011.

[4] Kusrini, J.E. Istiyanto, Penyelesaian Travelling Salesman Problem Dengan Algoritma Cheapest Insertion Heuristics Dan Basis Data, Jurnal Informatika Vol. 8, No. 2, hal. 109 - 114, 2007.

[5] R.Adipranata, F. Soedjianto, dan W. Tjondro, Perbandingan Algoritma 
Exhaustive, Algoritma Genetika Dan Algoritma Jaringan Syaraf Tiruan Hopfield Untuk Pencarian Rute Terpendek. [Online]. Available: http://fportfolio.petra.ac.id/user.../Perbandi ngan\%20Rute\%20Terpendek.pdf.

[6] Suyanto, Algoritma Optimasi : Deterministik atau Probabilistik, Yogyakarta: Graha IImu, 2010. 